\section{Pisma odurzajce. Excitantia': amfetamina i ecstasy}

\section{Cécile Guilbert}

TEKSTY DRUGIE 2021, NR 1, S. 267-281

DOI: $10.18318 /$ td.2021.1.16
Tekst jest tłumaczeniem wstępu do części IV Excitantia, literackiej antologii poświęconej substancjom odurzającym autorstwa Cécile Guilbert Écrits stupéfiants: drogues \& litterature d'Homère à Will Self, Robert Laffont, Paris 2019. (C) Bouquins, 2019

\section{Środek leczniczy}

Jako czysty wytwór świata uczonych, nauki i techniki XX wieku, a także „narkotyk przywódców opracowany z myślą o umysłach, które pragną dominować, przez umysły, które zdominowały naturę"2, amfetaminy mają się do dawnych środków pobudzających tak jak nadejście antropocenu do epoki nowożytnej: stanowią historyczną

1 Excitantia, czyli środki psychostymulujące, takie jak kawa, tytoń czy tytułowa amfetamina, stanowią odrębną kategorię substancji psychoaktywnych opracowanych przez niemieckiego farmakologa i toksykologa Louisa Lewina. Ze względu na efekty ich działania substancje psychotropowe, poza wspomnianymi już psychostymulantami, dzielą się w klasyfikacji Lewina na Inebriantia (substancje odurzające, dosł. "upajające"), Euphorica (substancje uspokajające), Hypnotica (substancje nasenne) oraz Phantastica (substancje halucynogenne). „Bardziej literacka niż medyczna” klasyfikacja ta została przyjęta przez Cécile Guilbert jako najodpowiedniejsza do założeń antologii, z której pochodzi niniejszy fragment (przyp. tłum.).

2 T. McKenna Food of the Goods: The Search for the Original Tree of Knowledge. A Radical History of Plants, Drugs and Human Evolution, Bantam, New York 1998.
Cécile Guilbert - ur. 1963 w Pau, francuska pisarka i krytyczka literacka związana z kontrkulturą. Jest autorką m.in. esejów o księciu de Saint-Simon, Guy Debordzie oraz o Laurence Sternie. W jej dorobku znalazły się także powieści, m.in. Le Musée national, oraz antologia literacka Écrits Stupéfiants, drogue \& litterature d'Homère à Will Self, będąca syntezą wieloletnich refleksji nad rolą substancji odurzających w literaturze. W 2008 roku za esej Warhol Spirit otrzymała nagrodę Médicis. 
mutację bezpośrednio związaną z narodzinami biopolityki. U zarania nowej estetyki szybkości, pędu i maszyny, której pierwsze sygnały znajdziemy w Manifeście futuryzmu z 1909 roku, substancje te należą do najpotężniejszych stymulantów ośrodkowego układu nerwowego o działaniu porównywalnym do adrenaliny. Tym, co wyróżnia te pierwsze syntetyczne substancje psychoaktywne, jest fakt, że przez długi czas uznawano je nie za "narkotyki” (ani nawet nie za narkotyki mogące znaleźć zastosowanie w medycynie, jak niegdyś morfina i kokaina), lecz za prawdziwy ś r o d e k le c z n i c zy. Środek leczniczy „wielkiego zdrowia” w nietzscheańskim znaczeniu tego terminu: pobudzający, stymulujący, euforyzujący, tonizujący. Cudowny w skutkach zarówno dla jednostki chorej, jak i całkowicie zdrowej. Preparat o działaniu par excellence „hedonizującym”, mający niezaprzeczalną wartość społeczną i z tego też powodu przez dziesięciolecia masowo przepisywany zachodniej populacji niezależnie od klasy społecznej.

\section{Chemiczne panaceum}

Amfetaminę po raz pierwszy otrzymuje drogą syntezy rumuński chemik Lazăr Edeleanu w 1887 roku. Interesuje go jednak wyłącznie chemiczny aspekt tego odkrycia i nie zdaje sobie sprawy z jej właściwości fizjologicznych. W tym samym roku Nagayoshi Nagai dokonuje ekstrakcji alkaloidu z przęśli chińskiej - niewielkiego krzewu o żółtych kwiatach i czerwonych owocach, dobrze znanego w tradycyjnej medycynie chińskiej. Otrzymana w ten sposób naturalna substancja nazwana efedryną rozkurcza oskrzela, stymuluje pracę serca i eliminuje łaknienie. Substancję tę, zsyntetyzowaną w 1928 roku przez Gordona Allesa, który eksperymentuje z jej użyciem na sobie, American Medical Association ochrzci mianem Alfa-Metylo-FenyloETyloAMINA - stąd pochodzi akronim używany jako jej nazwa generyczna. Wprowadzona na rynek pod nazwą benzedryny, przepisywana jest w formie tabletek bądź kapsułek przy blisko czterdziestu dolegliwościach, takich jak astenia, depresja, zmęczenie, otyłość, pokrzywka, epilepsja, choroba Parkinsona, choroba morska, zaburzenia seksualne, migreny etc. Najprawdziwsza „chluba chemii”, stymulująca elokwencję, ekscytację, euforię, siłę i zaufanie, uchodzi za odpowiednią dla znużonego dokuczliwie powtarzalnymi czynnościami robotnika i dla gospodyni domowej, dla proletariusza i dla intelektualisty. Tym bardziej że otwarcie głosi się jej nieszkodliwość, co nie jest prawdą, bo poza tym, że przy zbyt dużej dawce możliwa jest intoksykacja, w następstwie której mogą wystąpić konwulsje, 
a nawet śpiączka, okaże się także, że „chroniczne zażywanie amfetamin długofalowo prowadzi do upośledzenia centralnego układu nerwowego, krwionośnego i pokarmowego"3.

W tym samym czasie w Niemczech, które z racji prężnie działającego przemysłu chemicznego i farmaceutycznego od XIX wieku stanowiły istną narkotykową potęgę, doktor Fritz Hauschild (po wojnie stanie się jednym z najważniejszych lekarzy sportowych w NRD oraz twórcą planu dopingowego dla lekkoatletów) udoskonala efedrynę i wiosną 1937 roku za pomocą nowej metody syntezy otrzymuje metamfetaminę. Uzyskana substancja zdobywa patent i zostaje wprowadzona na rynek pod handlową nazwą pervitin. Nowe panaceum, deklasujące benzedrynę pod względem siły i czasu działania, urynkowione na wzór coca-coli, spada niczym bomba i błyskawiczne się rozprzestrzenia, uderzając bezpośrednio w nazistowskie społeczeństwo produkcyjne wraz z jego obsesyjnym pragnieniem nadsiły. Rozdawana setkom tysięcy żołnierzy, jak również zażywana przez samego Hitlera, „narodowa amfetamina"4 skłania, by postrzegać wojnę i eksterminację Żydów jako „pracę do wykonania”, a także częściowo tłumaczy zatrważający blitzkrieg Wehrmachtu na wielu frontach od 1939 do 1941 roku. Rzuca ponadto światło na uzależnienie przyszłego laureata literackiej Nagrody Nobla Heinricha Bölla, żołnierza klasy pierwszej, który nieustannie domagał się od swojej rodziny paczek z pervitinem i również po zakończeniu wojny nie zaprzestał korzystania z jego „cudownych właściwości”.

\section{Cywilne następstwa wojskowej kuracji: amerykańska męka}

Szybkość, poczucie wyższości, intensywność: te zalety benzedryny i pervitinu zostają po 1945 roku spotęgowane przez dexedrynę przyjmowaną w znacznych ilościach przez amerykańskich żołnierzy podczas wojny w Korei, Wietnamie, a nawet Afganistanie w 2002 roku (go-pill program). Wszystkie te łatwo dostępne, tanie i przepisywane na prawo i lewo przez lekarzy substancje dają początek nowej kulturze frenetycznego porywu i wolności, która odciśnie piętno na wszystkich sferach ludzkiej aktywności w latach 6o. i 70. W Stanach Zjednoczonych

3 R. Verbeke Un dictionnaire critique des drogues, Christian Bougeois, Paris 1978.

4 N. Ohler L'Extase totale, le Ille Reich, les Allemands et la drogue, la Découverte, Paris 2016.

5 H. Böll Briefe aus dem Krieg 1939-1945, Kolonia, Kiepenheuer und Witsch, 2001, cytowany w: N. Ohler, L'Extase totale. 
lista zagorzałych speedfreaks ${ }^{6}$ nie ma końca: aktorka Judy Garland, piosenkarze Elvis Presley, Hank Wiliams i Johny Cash, pisarz Truman Capote, poza tym Charles Manson i John F. Kennedy, a także kolarz Tom Simpson i czeski biegacz Emil Zátopek. Inną grupą regularnych konsumentów amfetaminy są „wielkie gwiazdy" z The Factory, takie jak Edie Sedgwick i Ondine, a także sam Andy Warhol, który, uznając w tamtych czasach sen za "przeżytek", rejestruje monologi i dialogi amfetaminowe swoich przyjaciół, aby z ich transkrypcji stworzyć swoją jedyną „powieść”, a, A Novel (1968), w której tytule pierwsza litera alfabetu stanowi aluzję do slangowego określenia konsumentów amfy, tzw.A-heads, zaopatrywanych przez słynnego doktora Charlesa Robertsa. Inny wytwór tamtych czasów, The Amphetamine Manifesto (1972), przynosi dokumentalno-poetycki wgląd w świat niewielkiej społeczności uzależnionych od amfetaminy przyjaciół autorstwa niejakiego Harveya Cohena, po którym próżno dzisiaj szukać śladu. Ta składanka relacji z tripów - solowych i zbiorowych - a także zdjęć i transkrypcji wypowiedzi stanowi zbiór portretów rozgorączkowanych i nadaktywnych artystów, którzy pragną intensywniej doświadczyć egzystencji. Rozdarty pomiędzy entuzjazmem a antycypowaną nostalgią Cohen prorokuje - słusznie zresztą - że „kultura amfetaminy stanowi swego rodzaju miniepokę, wydarzenie w dziejach ludzkości, które zniknie równie pewnie i nieodwracalniejak Paryżlat 20. czy San Francisco lat 6o."7.

Szeroko rozpowszechnionymi także na Zachodnim Wybrzeżu (Haight-Ashbury, dzielnica San Francisco, uchodzi w owym czasie za światową stolicę amfetaminy) tzw. benzinami delektują się twardziele odrzucający hipisowską kulturę bycia cool: hardrockowcy, gangsterzy z Hell's Angels, jak również wszyscy ci, którzy opowiadają o wyczynach wyżej wspomnianych. Wśród nich są Lester Bangs (1948-1982), człowiek, który krytykę rocka wyniósł do rangi literatury, a także Hunter S. Thompson, twórca „nowego dziennikarstwa" - dwaj postrzeleńcy oraz zagorzali speedfreaks, których uwadze nie umyka nierozerwalny związek między frenetycznym pisaniem na maszynie a kulturą speedu. Intuicja ta błyskotliwie zilustrowana została w jednym z artykułów Bangsa o opóźnionym wpływie niemieckiej metamfetaminy na robotyczny rock zespołu Kraftwerk:

Jak wiemy, Niemcy wynaleźli metamfetaminę, która spośród wszystkich innych dostępnych środków najbardziej zbliżyła człowieka do maszyny.

6 Tj. uzależnionych od amfetaminy. Po angielsku amfetaminę potocznie określa się jako speed.

7 H. Cohen The Amphetamine Manifesto, Olympia Press, Paris 1972. 
Bez metamfetaminy nigdy nie mielibyśmy tak elektryzujących figur kontrkultury, jak Lenny Bruce, Bob Dylan, Lou Reed czy Velvet Underground, Neal Cassady, Jack Kerouac, Howl Allena Ginsberga, Blue Cheer, Cream i Creem [...]. Łatwo można więc wywnioskować, że tak naprawdę to Ni e m cy są odpowiedzialni za Blonde on Blonde czy On the Road - Rzesza nigdy nie umarła, jedynie przeistoczyła się w amerykańskie archetypy zmaterializowane pod postacią manekinów o pustych oczach przykutych do swoich maszyn do pisania i gitar, rozdygotanych jak kopulujące nosorożce. $^{8}$

Jeśli więc chodzi o writing i typing, to niewątpliwie dopiero Beat Generation zawdzięczamy literacką nobilitację speedu, nie tyle przez sam opis jego działania, ile przez fakt, że jej główni przedstawiciele masowo tworzyli pod jego wpływem' Trzeba przeczytać płomienne i głębokie listy Neala Cassady'ego ${ }^{10}$, żeby pojąć, co takiego przyniosło owo nowe wejrzenie w duchowy wymiar egzystencji na „falach szczególnej energii, która majestatycznie sączy się z paseczków benzedryny"11. Wtajemniczony przez Haldona Chase'a na ławeczce w jego sali do bilardu Cassady stanie się wkrótce dilerem, piewcą i gorliwym wyznawcą benzedryny, co ostatecznie w 1968 roku przypłaci życiem, umierając w wieku czterdziestu dwóch lat. Jego przyjaciel Jack Kerouac jako student na Uniwersytecie Columbia w listopadzie 1945 roku pod wpływem Allena Ginsberga również ulega jej urokowi: „Benzedryna pozwoliła mi zrozumieć wiele rzeczy. Proces intensyfikacji uwagi prowadzi naturalnie do pogrzebania dawnych wyobrażeń i oto nowa materia wyłania się niczym tryskająca woda na krańcach świadomości. Całkowicie nowa woda!". Byłoby jednak niemalże obelgą wobec literackiego geniuszu Kerouaca, gdyby chcieć go potraktować na równi z kolegami z tej wielkiej kąpieli chemicznej, a tym bardziej jego „podstawy spontanicznej prozy” sprowadzić do zażywania speedu. Z kolei w rodzinie Burroughsów amfetamina zajmuje szczególne miejsce. O ile bowiem powszechnie wiadomo, że William nie gustował w substancjach

8 L. Bangs Kraftwerkfeature, Creem, wrzesień 1975, s. 30.

9 Na ten i inne tematy zob. J. Long, Drugs and the „Beats", the Role of Drugs in the Lives and Writing of Kerouac, Burroughs and Ginsberg (wydane własnym sumptem przez autora w 2005).

10 N. Cassady, Un truc très beau qui contient tout: lettres 1944-1950, Finitude, Bordeaux, 2014; Dingue de la vie \& de toi \& de tout: lettres 1944-1958, Finitude, Bordeaux 2015. 
pobudzających ${ }^{12}$, to jego żona, Joan Vollmer, wyraźnie ich nadużywała. Ich syn, William Burroughs Jr, pozostawił następującą relację ze swoich narodzin:

Moja matka była niewątpliwie niezwykłą kobietą. Ilość benzedryny, którą zażywała każdego dnia mojej prenatalnej egzystencji, wystarczyłaby, żeby za jednym zamachem zabić Lestera Maddoxa, natomiast Big Bill, mój ojciec, by nie trafić na boczny tor, jechał we właściwym sobie wegetatywno-kontemplacyjnym stylu na trzech szprycach heroiny dziennie. Nim się obejrzeli, zjawiłem się na naszej fermie w Rio Grande... ${ }^{13}$

Atawizm, szczególna skłonność do uzależnień i rodzicielskie zaniedbania zaciążą na losie „Billy'ego”, który również wpadnie w sidła nałogu i zostanie autorem Speed (1970), przełomowej powieści autobiograficznej poświęconej amfetaminie. „Spójna opowieść osnuta wokół jednego tematu, który jednak wydaje się a priori nieuchwytny, to znaczy świata metedryny", pisze w przedmowie Allen Ginsberg, notabene uczestnik kontrkulturowej kampanii skierowanej w latach 6o. przeciwko amfetaminie - „Speed Kills”.

Poza tym warto wspomnieć również o przyjacielu wyżej wymienionych, często powracającym na kartach ich książek, którego spotkaliśmy już w dziale Heroina. Herbert Huncke, ikona Beat Generation, pierwowzór h i p s t e r a , pół włóczęga, pół rzezimieszek był wielkim amatorem benzedryny, którą uwielbiał wstrzykiwać sobie w toaletach podejrzanych spelunek. Jego pośmiertnie wydane wspomnienia zawierają krótką Ustną historię benzedryny w Stanach Zjednoczonych. Podobnie Graham Greene wyzna w swojej ostatniej autobiograficznej książce Ways of Escape (1980), że nadużywanie benzedryny „przyczyniło się do rozpadu [jego] małżeństwa bardziej niż rozłąka spowodowana wojną i [jego] własne zdrady":

Wracałem do domu o piątej, z drżącymi dłońmi, w oczekiwaniu aż kolejny stan depresyjny spadnie na mnie z regularnością tropikalnego deszczu.

Pierwsze zażycie amfetaminy ze swoją przyjaciółką Mary wspomina tak: „Zacząłem mówić bardzo szybko. Miałem sucho w ustach, a moje plwociny wyglądały jak białe kulki - nazywa się to pluciem bawełną. Potem łaziliśmy dokoła Times Square. Mary zależało na znalezieniu kogoś, kto ma flet pikolo, mnie natomiast przepełniała bezgraniczna wszechżyczliwość i nagle doświadczyłem chęci złożenia wizyty ludziom, których nie widziałem od miesięcy, a nawet lat, ludziom, których nie lubiłem i którzy nie lubili mnie", W. Burroughs Ćpun, przeł. A. Ziembicki, R. Januszewski, Amber, Warszawa 2004, s. 46.

Cyt. za: C. Vilà Wiliam Burroughs, le genie empoisonné, Éditions du Rocher, Monaco 1992. 
Długo po upływie sześciu tygodni zmuszony byłem podjąć kurację, zmniejszając dawki, by wyjść ze stanu uzależnienia. Karierze pisarza przypisane są odrębne, osobliwe formy piekła. ${ }^{14}$

\section{Amfetaminy a literacka produktywność}

Dostępne we Francji w wolnej sprzedaży aż do 1955 roku orthédrine i maxiton (nazwy handlowe benzedryny) stanowią nieodłączny składnik procesu twórczego wielu pisarzy. I tak na przykład Jean-Paul Sartre wspomaga się corydrane w pracy nad Krytyką dialektycznego rozumu, jak również nad swoimi przerysowanymi opracowaniami na temat Jeana Geneta i Flauberta.

Proszę zauważyć, że zawierzenie corydrane - odpowie w 1974 roku na pytanie „Bobra” 15 - było niczym podążanie za światem wyobrażeń; stan, którego doświadczałem po zażyciu dziesięciu tabletek rano podczas pracy, pozwalał na całkowite oddzielenie się od ciała; doświadczałem siebie poprzez ruchy pióra, wyobrażenia i idee, które się we mnie kształtowały; stawałem się tym aktywnym bytem, jakim był Pardaillan. ${ }^{16}$

Tym bardziej, że do tych 200 miligramów amfetaminy Sartre dorzucał każdego dnia

dwie paczki papierosów - boyardów w papierze kukurydzianym - wiele fajek nabitych brązowym tytoniem; ponad litr alkoholu - wina, piwa, białych alkoholi, whisky itd. [...] piętnaście gramów aspiryny; dużo gramów barbituranów, nie licząc kaw, herbat i tłuszczów w swojej codziennej diecie. $^{17}$

W tych samym czasie - w latach 50. - młody Gabriel Matzneff, odkąd skończył trzynaście lat aż do matury w liceum Carnot, zażywa co noc do

14 Tłum. za: G. Greene Les Chemins de l'évasion, Robert Laffont, Paris 1980.

15 Jean-Paul Sartre zwykł zwracać się w ten sposób do Simone de Beauvoir. Za twórcę tego przydomka uznaje się René Gabriela Eugène'a Maheu, profesora filozofii, attaché kulturalnego w Londynie i przyjaciela towarzyszki życia Sartre'a - po angielsku beaver, bóbr, wymawia się prawie tak jak nazwisko de Beauvoir (przyp. tłum.). 
pięciu maxitonów: „To pozwalało mi zwalczyć zmęczenie, pobudzało, poddawało genialne pomysły!" - wspomina czterdzieści lat później ${ }^{18}$. Podobnego zdania jest Philippe Sollers, który tak jak Philippe Muray wspomaga się w latach 70. captagonem: „Znalazłem zaufanego lekarza, który wypisywał mi recepty, i zażywałem to z poranną kawą na błyskawiczny początek dnia. Cud. Jedna tabletka i od razu byłem gotowy do pisania"19.

Fenetylina, kuzynka amfetaminy i składnik aktywny captagonu, została udoskonalona przez doktora Karla-Heinza Klingera pod koniec lat 50. Ten swego rodzaju smart drug miał mieć wszystkie pożądane cechy speedu i jednocześnie żadnych skutków ubocznych. Obecnie captagon znów święci triumfy, zwłaszcza na Bliskim i Dalekim Wschodzie, o czym świadczą rekordowe konfiskaty. Ten modny narkotyk imperiów naftowych, który rzekomo masowo mają przyjmować również bojownicy ISIS i dżihadyści, stał się przedmiotem wielu dyskusji starających się odpowiedzieć na pytanie, czy autorzy ataków terrorystycznych działają pod jego wpływem.

Po odstawieniu heroiny w 1974 roku także dziennikarz i pisarz Yves Salgues przechodzi na préludine. O swoim doświadczeniu opowiada ze swadą:

Doznajemy jakby powiększenia mózgu. Nim upłynie kwadrans, czujesz, że umysł zaczyna się rozszerzać, stajesz się panem świata. Po zażyciu napisałem powieść na dwa tysiące stron o niewidomym geniuszu. To narkotyk, stymulant oddziałujący na centralny układ nerwowy z niewiarygodną silą. Pojąłem wówczas to, co Sartre wyznał mi pewnego razu: za sprawą corydrane jego tekst Święty Genet. Aktor i męczennik (1952) z przedmowy przeistoczył w tomiszcze. ${ }^{20}$

\section{Od przypadku Dicka do ruchu cyberpunkowego}

Philip Kindred Dick (1928-1982) nie figuruje, niestety, na kartach tej antologii, a z pewnością zasługiwałby na jedną w całości poświęconą tylko jemu (podobnie jak temat narkotyków - bądź to inspirowanych substancjami

18 Na temat tego "wspaniałego intelektualnego leku przeciwbólowego" oraz objawów głodu narkotykowego zanotowanego przez Muraya, por. Ultima Necat II, journal intime 1986-1988, Les Belles Lettres, Paris 2015.

S. Des Déserts Captagon, enquête sur la drogue des terroristes, „Vanity Fair” 2016 nr 34. 
istniejącymi lub pochodzących od nich, bądź to będących czystym wytworem wyobraźni - wszechobecny w literaturze science fiction, który wystarczyłby na osobny tom Pism odurzajacych ${ }^{21}$ ). Warto jednak przywołać tutaj jego postać, a to $\mathrm{z}$ dwóch powodów: jako frenetycznego konsumenta amfetaminy oraz pisarza, który do ekstremum doprowadził refleksję nad wpływem technologii na mutację i odczłowieczenie gatunku ludzkiego. Hipochondryk i paranoik, nadużywał środków psychotropowych - psychodelików (LSD), meskaliny, ale przede wszystkim semoxydrine, odmiany metamfetaminy, która pozwoliła mu napisać pierwsze opowiadania i nowele fantastycznonaukowe (czasopisma płaciły za nie od sztuki). Dzięki tej przebogatej diecie między 1963 a 1964 rokiem udaje mu się napisać kilkanaście powieści science fiction, jak również niezliczone opowiadania i eseje, jednak amfetamina coraz częściej zaczyna wywoływać u niego stany depresyjne. Czy apogeum tego okresu stanowi jednocześnie zapowiedź wielkiego tematu - mechanicznej hybrydyzacji człowieka - który stanie się odtąd integralną częścią jego dzieł? Przywołajmy Trzy stygmaty Palmera Eldritcha (1965), następnie Czy androidy marzą o elektrycznych owcach? - powieść przeniesioną na ekran w 1982 przez Ridleya Scotta jako kultowy już dzisiaj Blade Runner - wreszcie Ubika (1969). Gdy rozpada się jego czwarte małżeństwo, Dick otwiera drzwi kalifornijskiego domu w Santa Venetia przed przygodnymi narkomanami wszelkiej maści, sam zaś zaczyna nałogowo konsumować liczne substancje, zwłaszcza metedrynę, której zdarza mu się przyjmować nawet ponad 1000 (sic!) tabletek tygodniowo. To ponury okres, w którym napisze Przez ciemne zwierciadło $(1977)^{22}$, a w jego umyśle zrodzą się teorie spiskowe z udziałem CIA, które zawiodą go prosto do zakładu dla umysłowo chorych. Potem przyjdą jeszcze medytacja gnostyczna i religijne ekstazy inspirowane objawieniem zesłanym przez penthotal, środek uspokajający, który zjawi się w porę, by zapłodnić umysł od dawna przepełniony pragnieniem transcendencji.

Rywalizacja pomiędzy światem realnym i wirtualnym oraz mnogość światów równoległych - iście Dickowskie terminy - stały się inspiracją

21 Na ten temat por. bogate opracowanie François Rouillera Stups \& fiction, drogue et toxiomanie dans la science-fiction, Encrage-Les Belles Lettres, Amiens-Paris 2002.

Będąca swoistym porachunkiem ze światem narkotyków powieść A Scanner Darkly (wyd. pol. Przez ciemne zwierciadło, przeł. T. Jabłoński, Rebis, Poznań 1997) przedstawia portret Boba Arctora, tajnego agenta na usługach brygady antynarkotykowej, który uzależnia się od pewnej substancji halucynogennej powodującej poważne uszkodzenia mózgu. Zażywanie "substancji A" powoduje, że Arctor zaczyna śledzić samego siebie kosztem imponującego schizofrenicznego rozszczepienia osobowości. 
dla nurtu cyberspace, a zwłaszcza dla cyberpunku. Termin ten, ukuty w 1983 przez amerykańskiego krytyka i pisarza Gardnera Dozois, odnosi się do nurtu zapoczątkowanego przez Wiliama Gibsona powieścią Neuromancer, która w 1984 roku „była dla SF niczym elektrowstrząs”23. Żywo zainteresowany cybernetyką Gibson spłodził wcześniej dwie historie o szpiegach przemysłowych zmagających się z międzynarodowymi korporacjami, które zresztą doczekały się adaptacji filmowych: Johny Mnemonic (reż. Robert Longo, 1995) oraz Hotel New Rose (reż. Abel Ferrara, 1998). Bezpośrednie połączenie mózgu z komputerem czy nowy środek uzależniający, jakim jest przepływ informacji, nie przeszkadzają nowej narkomanii high tech współistnieć z bardziej klasycznymi odmianami, toteż substancje w rodzaju wizz, Beta-P czy dex - niezbyt przyjemne protezy chemiczne wymyślone przez Gibsona - wypełniają ponury i autodestrukcyjny świat jego prozy. Inny autor SF Neal Stephenson, którego powieść Zamieć (1992) zapoczątkowała nurt postcyberpunku, opisuje z kolei roznoszącą się niczym zaraza substancję na bazie kokainy i surowicy zakażonej krwi, której istotą jest ścisłe połączenie narkotyku, wirusa i religii.

\section{Narodziny MDMA}

Nasilająca się prohibicja sprawia, że amfetaminy uginają się pod naporem wprowadzonej w życie w 1971 roku Konwencji o substancjach psychotropowych, nie dają jednak za wygraną - ciągłość nielegalnej produkcji metamfetaminy nigdy nie została przerwana - a nawet z końcem XX wieku, przy okazji stworzenia nowego środka psychoaktywnego o nazwie MDMA, przeżywają spektakularny renesans. „Ojciec” tej zsyntetyzowanej po raz pierwszy w 1898 roku substancji, kalifornijski chemik Alexander Shulgin (1925-2014) - swego rodzaju współczesny doktor Jekyll - jest autorem ważnych eksperymentów z wykorzystaniem substancji psychotropowych, które prowadził w swoim prywatnym laboratorium wraz z żoną Ann. Zainspirowany nową klasyfikacją substancji psychoaktywnych, wprowadzoną w 1957 roku przez psychiatrę Jeana Delaya, który za kryterium podziału uznał efekt ich oddziaływania na ludzką psychikę, Shulgin pragnął stworzyć nową "farmakologię świadomości”, wywołując nieznane dotąd efekty za pomocą opracowanych przez siebie nowych substancji, powodujących zmianę stanu świadomości. Bardziej niż użyciem w celach rekreacyjnych, artystycznych, czy nawet naukowych, Shulgin

23 F. Rouiller Stups \& fiction... 
był zainteresowany filozoficznym wymiarem swojej pracy. Poznaniem, którego dostarczał dany produkt. Jego heurystyczną wartością. Tym, w jaki sposób i w jakim stopniu otwierał drzwi, które bez tego doświadczenia pozostałyby zamknięte. Poza utartymi już metaforami, które owe drzwi określają - jak ta mówiąca o "nowej przestrzeni” czy też „nowym horyzoncie” - szczególnie wymowna jest metafora „bibliofila”:

Umysł ludzki - mówi Shulgin - podobny jest do półek gigantycznej biblioteki. Książki najczęściej wybierane przez czytelników są łatwo dostępne - wyłożone na stołach i drabinkach są, by tak rzec, na wyciągnięcie ręki. Inne natomiast stoją na półkach i by móc się z nimi zapoznać, trzeba bardziej skupionej uwagi, silniejszej woli poznania. Niektóre woluminy są umieszczone na wyższych piętrach biblioteki. W przypadku okazjonalnego gościa, którym wszyscy zresztą jesteśmy, te wyższe piętra zdają się pełnić funkcje raczej dekoracyjne niż praktyczne i użytkowe. Żadne widoczne gołym okiem schody nie pozwalają się tam dostać, toteż stojąc na dole możemy dostrzec jedynie kolorowe grzbiety ustawionych tam ksiąg. Dystans, który nas od nich dzieli, nie pozwala odczytać tytułu czy choćby autora dzieła. Substancja psychoaktywna - zdaniem Shulgina - wskazuje, gdzie znajdują się schody prowadzące do wszystkich tych woluminów.

\section{Ekstazy, nowy zbiorowy narkotyk końca wieku}

W pasjonującej, napisanej jak powieść książce autobiograficznej PiHKAL ${ }^{24}$ Shulgin opisuje sposoby syntezy 200 różnych pochodnych fenyloetyloaminy, jak również eksperymenty, które przeprowadzał na sobie, związane w szczególności z doświadczaniem różnego typu muzyki, których nie sposób byłoby tu zreferować. MDMA, najbardziej wyjątkowy ze związków, które opracował w ramach szeroko zakrojonych badań, odznacza się niezwykłą właściwością, wykraczającą poza oniryczny wpływ psychodelików i elektryzujące działanie stymulantów: środek ten potrafi oddziaływać na emocje, pozwalając tym samym na przekraczanie własnych barier i „robienie nowych rzeczy z samym sobą". Jego użycie, pobudzające szczerość i zdolność ekspresji, ułatwiające komunikację pomiędzy terapeutą a pacjentem, zaczęto niebawem zalecać w ramach terapii psychoanalitycznych ze względu na niepodważalne zalety

24 Skrót od: Phenethylamines I Have Known And Loved: A Chemical Story Of Love, Transform Press, Berkeley 1991. 
terapeutyczne. W połowie lat 8o. substancję tę, określaną jako „empatogenna" (generująca empatię), produkuje w ogromnych ilościach pod nazwą handlową ecstasy teksańskie przedsiębiorstwo. Rodzi się wówczas nowa scena kulturalna, owoc zderzenia empatogennej substancji z wynalazkiem z Ibizy, jakim jest muzyka techno. Ekstrawertyzm, empatia, pacyfizm, czułość ocierająca się o fuzję erotyki i emocji: doznania te, wzmagane hipnotycznym i jednostajnym rytmem, zapewnią sukces zarówno substancji, jak i muzyce. W przeciwieństwie do poprzedniczek i z racji własnej specyfiki ecstasy jest narkotykiem nastawionym na grupę, społeczność, zbiorowość - czy będzie to rave, czy też klub nocny. Łatwo dostępna, niedroga, przez długi czas uważana za stosunkowo mało szkodliwą i niepowodującą uzależnienia, mimo że zakazana w 1988 roku, „mała okrąłła pastylka”, która tak jak niegdyś „listki” LSD występuje w najróżniejszych kolorach i jest ozdobiona różnymi symbolami, staje się modnym narkotykiem lat 90.

\section{Literackie ekstazy}

Ecstasy, obiekt niemałej fascynacji zachodniej młodzieży, przeżywa moment literackiej chwały w latach 9o., gdy swoje powieści piszą Ryū Murakami, Irvine Welsh, Douglas Rushkoff i Frédéric Beigbeder, do których niedługo potem dołączą także inni młodzi aspirujący autorzy ${ }^{25}$. Urodzonemu w 1952 roku Ryū Murakamiemu uznanie przyniosła sprzedana w ponad milionie egzemplarzy pierwsza powieść Bezgranicznie prawie przezroczysty błękit (1977), w której miejsce centralne zajmują heroina, meskalina i haszysz widziane przez pryzmat ekscesów grupy zdradzających autodestrukcyjne tendencje nastolatków. O ile jeszcze w Liniach, polifonicznej powieści o samotnych i zdesperowanych bohaterach, Murakami wspomina - dość płasko - o amfetaminie, o tyle w Ecstasy (1993) czytelnik odnajdzie najświetniejsze opisy działania kokainy i oczywiście MDMA, „produktu, który roznieca płomień zmysłów i podsyca pożądanie aż do najdalszych granic", a jednocześnie zdolnego „wywołać dość spektakularne wahania nastroju”.

Odtąd, zbanalizowane, choć wciąż popularne i obecne we współczesnej literaturze MDMA wzbudza zauważalnie mniejszy entuzjazm. Opisy „zjazdów" po jego zażyciu (nieodmiennie nieprzyjemne w przypadku pochodnych amfetaminy) wydają się brać górę nad domniemanymi zaletami. Symptomatyczna w tym kontekście wydaje się poruszająca powieść Louisiane C. Dor

25 Por. np. S. Champion Disco Biscuits, Hodder ans Stoughton, London 1997. 
Les méduses ont-elles sommeil?, w której ecstasy, występujące pod dawną nazwą chemiczną, MDMA, pogrąża młodą narratorkę w mdlącej otchłani rozpaczy i wiedzie na zatracenie. Okazuje się tym bardziej zdradzieckie, że bohaterka nigdy nie ma wrażenia, że bierze „narkotyk”. Tymczasem czekają ją kolejne bad tripy i roztrząsanie ad nauseam własnej pustki i udręki:

Moje życie jest gówniane, nawet w towarzystwie czuję się sama, kręcę się w miejscu, aż dostaję od tego zawrotów głowy. Nic mnie nie cieszy - nie chcę być w domu ani na zewnątrz, ani jeść, ani czuć głód, ani spać, ani stać. [...] Czuję się równie słaba zewnętrznie, co w środku. Jestem mniej niż niczym. Jestem nikim. ${ }^{26}$

\section{GHB i nowe produkty syntetyczne}

Syntezy GHB (kwasu 4-hydroksymasłowego), nazywanego pigułką gwałtu, dokonał w 1961 roku francuski psychiatra Henri Laborit. Substancja ta, trudna do zaklasyfikowania, bo jednocześnie znieczula i hipnotyzuje, stała się pod koniec lat 9o. tematem kampanii medialnych wyolbrzymiających problem. Mimo że w połączeniu z alkoholem GHB może prowadzić do śpiączki, jego działanie afrodyzjakalne, odczuwalne szczególnie po zażyciu dużych dawek, sprawiło, że stało się ono, obok ecstasy, popularnym narkotykiem rekreacyjnym w klubach nocnych i dyskotekach. Nadużywają go bohaterowie Demain Berlin (2013), drugiej powieści Oscara Coop-Phane, w której jeden z nich przyjmuje GHB dożylnie:

Siada na sedesie, zakrywając twarz dłońmi. Muzykę słychać jak przez watę, drzwi toalety skutecznie ją tłumią. Zaczyna płakać. Czeka, aż to wreszcie w niego wejdzie. Wyciąga paczkę papierosów i przez moment zawiesza na niej wzrok. Oddycha głęboko, jak gdyby pragnął stracić jasność widzenia. [...] Po twarzy spływają mu łzy. Lekki kop GHB. Konwulsje, głowa uderza o ścianę, trzy, cztery, pięć razy. Przybiera dziwną pozycję, jakby jego zdezorientowane ciało zwlekało z decyzją, czy ma go podtrzymać. Jego ruchy są spazmatyczne, mimowolne drgnięcia kilku napinanych mięśni. ${ }^{27}$

L.C. Dor Les méduses ont-elles sommeil?, Gallimard, "Nos vies”, Paris 2016; wyd. 2. w kolekcji "Folio" - 2017. 
Ta nihilistyczna atmosfera przepełnia odtąd większość współczesnych powieści i opowiadań poświęconych narkotykom lub obierających je sobie za tło wydarzeń. Uderza to tym bardziej, gdy zdamy sobie sprawę, że zbiega się z niemożnością odróżnienia coraz nowszych i liczniejszych nielegalnych produktów obecnych na europejskim rynku od początku XXI wieku. Dobrym przykładem na ów nowy nadmiar nazewnictwa jest powieść Twelve ${ }^{28}$, opublikowana przez szesnastoletniego Nicka McDonella. Opisuje ona próżniacze życie bandy rozpuszczonych nastolatków z Nowego Jorku, ćpających nowe, mocniejsze od kokainy narkotyki.

Spośród setki nowych psychotropów otrzymywanych każdego roku drogą syntezy większość należy do rodziny katynonów, pochodnych substancji psychoaktywnej obecnej w czuwaliczce jadalnej, roślinie występującej w Jemenie i na Półwyspie Somalijskim, która od 2007 roku masowo zaczęła przedostawać się do Europy, a w 2012 roku została zaklasyfikowana jako narkotyk. Mefedron, metylon, 4-MEC, MDPV - nowe narkotyki zażywane pod postacią kapsułek bądź płynu sprzedawane są odtąd w internecie, ukryte za mnóstwem fantazyjnych nazw, z dawkowaniem równie niejasnym co niekontrolowalnym. Często mieszane ze sobą lub z alkoholem w ramach „rekreacji”, są obecnie w Paryżu przyczyną stale rosnącej liczby przedawkowann ${ }^{29}$. Jeśli zaś chodzi o nieustannie zwiększający się i jakże brzemienny w skutkach dla nowych form narkomanii wzajemny wpływ technologii i spożycia substancji odurzających, bez wątpienia należy zwrócić uwagę na rozwój „chemseksu” (dosłownie: chemicznego seksu, czyli seksu uprawianego pod wpływem narkotyków), który narodził się na początku XXI wieku w dużych miastach jako wypadkowa takich czynników, jak wynalezienie nowych produktów syntetycznych (zwłaszcza 3-MMC mającej intensyfikować doznania zmysłowe), pojawienie się aplikacji randkowych czy serwisów telefonicznych zapewniających klientom o każdej porze dnia i nocy narkotyki z dostawą do domu. Ograniczmy się do stwierdzenia, że ten nowy biochemiczny i społeczny model jest oddalony o lata świetlne od transcendentalnych dociekań postmodernistycznych pionierów, którzy otworzyli zamknięte wówczas drzwi percepcji.

Przełożyt Juliusz Cęcelewski

19 tynarkotykowej paryskiej policji sądowej i powołana do walki z narastającą wówczas w lawino-
wym tempie liczbą przedawkowań, jak również z handlarzami nielegalnych substancji, stała się
inspiracją dla książki Alexandre'a Kauffmanna Surdose, Goutte d'or, Paris 2008 . 


\section{Abstract}

\section{Cécile Guilbert}

Intoxicating Writings: Drugs and Literature from Homer to Will Self

The history of psychostimulants (amphetamine, methamphetamine, MDMA and GHB among many others) intersects with the social, political and literary history of the last century, it concerns new phenomena and social practices as well as novel tendencies in the arts. From the Dexedrine consumed by American soldiers in Korea and Vietnam through Alexander Shulgin's "pharmacology of consciousness," the emergence of cyberpunk and the popularity of ecstasy in the 1990s, to the nihilistic descriptions of drug-induced highs typical of twenty-first-century novels and short stories, Guilbert highlights the diverse ways in which the consummation of new synthetic intoxicating substances has impacted the history of the last century.

\section{Keywords}

intoxicating substances, drugs, amphetamine, ecstasy, GHB, twentieth-century literary history, twenty-first-century literary history, cyberspace, cyberpunk, history of counter culture 